\title{
Herbal Mouthwash for the Management of Oral Diseases: A Review on the Current Literature
}

\author{
Vrushali R Khobragade ${ }^{1}$, Prashanthkumar Vishwakarma ${ }^{2}$, Arun S Dodamani ${ }^{3}$, Minal M Kshirsagar $^{4}$, Sulakshana N Raut ${ }^{5}$, \\ Rahul N Deokar 6
}

\begin{abstract}
Several different varieties of mouthwashes are accessible to us nowadays, including chemical as well as herbal formulations. Appropriate mouthwash can be selected depending on the oral condition, risk, and efficiency of mouthwash. As mentioned in the literature also Mother Nature has provided us abundant medicinal herbs with antibacterial and antimicrobial properties. Though we are having very scarce data on the medicinal properties of these herbal plants, they are still in use in treating various periodontal diseases and other oral diseases. Knowing scientific expression of the actual effects of the herbal medicine is at most important for the beneficiaries. In the course of this bibliographical revision, papers were collected to validate the ancestral uses of herbs and conclude that the use of plants to treat oral conditions should be based on the experimental studies, verifying their suitability for dental treatments. Oral healthcare professionals would find this review helpful for accurate mouthwash selection while dealing with different conditions of the oral cavity.
\end{abstract}

Keywords: Herbal mouthwash, Oral disease, Review.

Journal of Oral Health and Community Dentistry (2021): 10.5005/jp-journals-10062-0085

\section{BACKGROUND}

Nowadays, oral diseases are known to be a big issue worldwide. Among numerous oral diseases, periodontal disease is one among the significant oral health condition. The quality of life is affected by oral health. Periodontal diseases are known to be chronic inflammatory conditions characterized by loss of connective tissue, alveolar bone resorption, and formation of periodontal pockets as a result of complex interaction between pathogenic bacteria and the host's immune response.

Dental plaque is being one of the primary etiologic factors in periodontal disease. ${ }^{1}$ Various plaque control measures are used to prevent or control the progression of periodontal diseases. One among it includes mechanical plaque control measures to maintain proper oral hygiene. ${ }^{2}$ A variety of different chemical plaque control measures are available in the market, which includes mouthwash, dentifrices, chewing gums, and gel. But they have some undesirable side effects, like vomiting, diarrhea, and tooth staining. Mouthwashes may serve as a measure in controlling dental plaque and periodontal disease for mentally or physically handicapped patients who are incapable of brushing their teeth themselves or other individuals who are lacking dexterity, skill, or motivation for mechanical plaque removal. ${ }^{3}$ Thus, instead of using them solely, mouthwashes should always be used in association with mechanical plaque control measures.

Ideally, it is required that any antimicrobial/antiseptic agents used should be able to modify the oral environment by being specifically effective against the pathogens without altering the normal flora. ${ }^{4}$ There are a number of mouthwashes available in the market today worldwide. Many of these mouthwashes have not been tested adequately, and the information is lacking as to when and how to use these agents for maximum benefit. ${ }^{5}$ Chlorhexidine digluconate has been the agent of choice as an antiplaque agent when compared to others and is considered the gold standard. However, due to its side effects, its acceptance by patients can be limited, especially when a longer period of use is recommended. ${ }^{6}$ \begin{tabular}{l}
\hline 'Department of Public Health Dentistry, VYWS Dental College and \\
Hospital, Amravati, Maharashtra, India \\
${ }^{2}$ Department of Preventive and Community Dentistry, ACPM Dental \\
College and Hospital, Dhule, Maharashtra, India \\
${ }^{3}$ Department of Public Health Dentistry, ACPM Dental College, Dhule, \\
Maharashtra, India \\
${ }^{4}$ Department of Public Health Dentistry, Nair Dental College and \\
Hospital, Mumbai, Maharashtra, India \\
${ }^{5}$ Department of Orthodontics, RRKDental College, Akola, Maharashtra, \\
India \\
${ }^{6}$ Department of Public Health Dentistry, SMBT Dental College and \\
Hospital, Nashik, Maharashtra, India \\
Corresponding Author: Vrushali R Khobragade, Department \\
of Public Health Dentistry, VYWS Dental College and Hospital, \\
Amravati, Maharashtra, India, Phone: +91 7020185738, e-mail: \\
vrushalikhobragade443@gmail.com \\
How to cite this article: Khobragade VR, Vishwakarma P, Dodamani AS, \\
et al. Herbal Mouthwash for the Management of Oral Diseases: A \\
Review on the Current Literature. J Oral Health Comm Dent 2021;15(2): \\
$70-77$. \\
Source of support: Nil \\
Conflict of interest: None \\
\hline \hline
\end{tabular}

Nowadays, the majority of people are choosing natural herbal products for the prevention or treatment of diseases. Plants being an abundant source should be considered in various pharmacological formulations. ${ }^{7}$ Ayurvedic medicinal plants are used in various treatments, as there are no or minimal side effects. For long-term use of mouthwashes, numerous mouthwashes have been tested in vitro and in vivo. ${ }^{7-13}$ Ayurvedic medicines give a holistic approach toward entire human beings. It can maintain the balance between general and oral health as well as an environment which is in this era necessary for the well-being of humans. 
This review will tend to be helpful for the oral healthcare professionals in the selection of mouthwashes depending on the condition.

\section{Review Results and Discussion Triphala}

The name "triphala" consists a mixture of amalaki, haritaki, and bahera. Its use in ayurveda is known since ages. By enhancing our body's capacity to form antibodies, it increases immunity. ${ }^{14}$

\section{Preparation of Triphala Mouthwash}

Add triphala powder (Terminalia bellirica, Terminalia chebula, and Emblica officinalis) (10 mL) to $10 \mathrm{~mL}$ of boiling water for preparing $10 \mathrm{~mL}$ of mouthwash.

\section{Side Effects}

No side effects have been reported.

In one of the reported study, triphala mouthwash has been prepared as follows:

Dissolve 60 grams of triphala churna in $1000 \mathrm{~mL}$ of doubledeionized water.

Boil it and filter. Then add $2 \mathrm{~mL}$ of glycerin and $1 \mathrm{~mL}$ of pudina extract. Glycerin works as a sweetening agent and pudina as a flavoring agent.

Cool the mixture, add $50 \mathrm{~mL}$ in amber-colored bottles. ${ }^{17}$

\section{Herbal Mouth Rinse Containing Tea Tree Oil (TTO), Clove, and Basil}

Ingredients include TTO (0.2-0.3\%), clove (0.2-0.3\%), and basil (0.2-0.3\%).

The mouth rinse was formulated by Anchor Health and Beauty Care Pvt. Ltd. (Mumbai, India). Minimum inhibitory concentration (MIC) of the mouth rinse was assessed by a broth macrodilution assay, which showed $25 \% \mathrm{MIC}^{15}$

\section{HiOra Mouthwash}

HiOra is the product of The Himalaya Drug Company, Makali, Bangalore, India.

In $1 \mathrm{~g}$ mouthwash solution, it contains $5 \mathrm{mg}$ pilu (Salvadora persica), $10 \mathrm{mg}$ Bibhitaka (Terminalia bellirica), $10 \mathrm{mg}$ Nagavalli (Piper betle), $1.2 \mathrm{mg}$ Gandhapura taila (wintergreen oil), $0.2 \mathrm{mg}$ ela, $1.6 \mathrm{mg}$ peppermint satva, and $0.4 \mathrm{mg}$ Yavani satva.

Rinse the mouth thoroughly by dispensing $15 \mathrm{~mL}$ of mouthwash for 30 seconds and expel it twice daily.

\section{Role of Ingredients}

Belleric Myrobalan (Bibhitaki) is known for its antimicrobial and antifungal properties.

Betel (Nagavalli) fights against halitosis and relieves toothache.

Meswak (S. persica) is a teeth cleaning agent.

Prevention of tooth decay and elimination of toothache and bad breath is the role of Pilu. ${ }^{16}$

\section{Garlic Extract Mouthwash}

Twenty-five grams of garlic extract powder was added into $1000 \mathrm{~mL}$ of deionized water. Boil and filter, then add $10 \mathrm{~mL}$ of pudina extract in it. Cool the mixture and dispense in amber-colored bottles. ${ }^{17}$

\section{Arimedadi Oil}

It consists of Lodhra, Lavang, Gairic, Agaru, Padmakashtha, Nagarmotha, Manjishtha, Jeshthamadh, Laksha, Welchi, Wadachi
Paane, Dalchini, Yashti, Jaiphala, Kapoor, Kankol, Kshudra chandan, Dhayati phoole, Khairchaal, Lahan welchi, Nageshar, Til tel. ${ }^{19}$

\section{Pomegranate Extract}

Pomegranate extract can be prepared from pomegranate peel extract (PPE), pomegranate aril extract, and pomegranate juice.

For preparing pomegranate mouthwash, pomegranate peels were desiccated in sunlight and overnight in a hot air oven at $60^{\circ} \mathrm{C}$ for 7 days. Then grind it in a powder consistency. Then, the acquired powder was used to prepare an aqueous extract in a Soxhlet extractor. Twenty grams of PPE was achieved at the end of 5 days.

Pomegranate aril extract is prepared by the same procedure but required to keep for 15 days for drying in a hot air oven at $60^{\circ} \mathrm{C}$.

Freshly prepared pomegranate juice can be obtained using the sterilized grinder. Four hundred milliliters of pomegranate juice when heated over 1 hour, it provides a heavy concentrate. ${ }^{18}$

\section{Salvadora persica L. and Green Tea}

In the manufacturing, Camellia sinensis var. assamica $(0.25 \mathrm{mg})$ is mixed with roots of S. persica L. (7.82 mg) extracts in $1 \mathrm{~mL}$ of distilled water. It is prescribed as $15 \mathrm{~mL}$ twice daily. Patient is asked to rinse for 30 seconds as well as refrain from eating or drinking for 30 minutes. $^{20}$

\section{Golnar Mouthwash}

Mix $10 \mathrm{~g}$ of dried golnar powder mixed with $40 \mathrm{~mL}$ of vinegar. Dilute the mixture to 1:5 with boiling distilled water, cool it, filter, and fill the preparation in an amber-colored bottle. On examination, the tannic acid content was recorded as $0.52 \mathrm{mg} / \mathrm{mL}$ and none of the five main pathogens which were examined for the study (Staphylococcus aureus, Shigella, Salmonella, Escherichia coli, and Candida) had grown on the related specific media. ${ }^{21}$

\section{Green Tea Mouthwash}

Green tea fragments were broken further into small pieces and soaked in $500 \mathrm{~mL}$ of ethanol for 48 hours. Filtered leaves were then kept in a hot air oven at $50^{\circ} \mathrm{C}$ for 3-4 days, and the extract was obtained. This $0.5 \mathrm{~g}$ extract is added to $100 \mathrm{~mL}$ of distilled water to constitute $5 \%$ green tea mouthwash. ${ }^{27}$

\section{Curry Leaves}

Fresh curry leaves which are available were dried under the sun for 3-4 days and thereafter crushed to obtain a fine powder. One hundred thirty-five grams of powder mixed in $4500 \mathrm{~mL}$ of distilled water to make the concentration of the solution as $3 \%$. The solution was dispensed in conical flasks and kept in a rotary shaker at 120 revolutions per minute ( $\mathrm{rpm}$ ) for 18 hours and then filtered. Ten milliliters of glycerin and $5 \mathrm{~mL}$ of Pudin Hara were added as sweetening and flavoring agents, respectively. ${ }^{29}$

\section{Neem Mouthwash}

Cut $100 \mathrm{~g}$ neem sticks into small pieces and blend into a coarse powder. Store the powder at room temperature. Soak the neem powder properly for a period of 2-4 hours and transfer it into a distillation apparatus along with 10 parts of water, and the mixture was constantly heated until $60 \%$ of the concentrate was collected. Cool it thoroughly and dissolve in $1000 \mathrm{~mL}$ of distilled water to constitute a $2 \%$ neem solution. ${ }^{30}$

\section{Tea Mouthwash}

Formulation of tea extract is done by mixing 7 tablespoons of green tea along with four cups of mineral water. The tea was steeped at 
Table 1: Previous literature available on herbal mouthwash

\begin{tabular}{|c|c|c|c|c|}
\hline $\begin{array}{l}\text { Author } \\
\text { and year }\end{array}$ & Title & Target population & $\begin{array}{l}\text { Sample size and } \\
\text { Study design }\end{array}$ & Conclusion \\
\hline $\begin{array}{l}\text { Naiktari } \\
\text { et al. }{ }^{14}(2014)\end{array}$ & $\begin{array}{l}\text { A randomized clinical trial } \\
\text { to evaluate and compare } \\
\text { the efficacy of triphala } \\
\text { mouthwash with } 0.2 \% \\
\text { chlorhexidine }(\mathrm{CHX} \text { in } \\
\text { hospitalized patients with } \\
\text { periodontal diseases }\end{array}$ & $\begin{array}{l}\text { Patients admitted in three } \\
\text { different medical hospitals }\end{array}$ & $\begin{array}{l}\text { One hundred twenty } \\
\text { patients double- } \\
\text { blinded, randomized, } \\
\text { multicenter clinical trial }\end{array}$ & $\begin{array}{l}\text { The triphala mouthwash (herbal) is } \\
\text { an effective antiplaque agent, like } \\
0.2 \% \mathrm{CHX} \text {. It is significantly useful } \\
\text { in reducing plaque accumulation } \\
\text { and gingival inflammation, there- } \\
\text { by controlling the periodontal } \\
\text { diseases in every patient. It is also } \\
\text { cost effective, easily available, and } \\
\text { well tolerable with no reported } \\
\text { side effects }\end{array}$ \\
\hline $\begin{array}{l}\text { Kothiwale } \\
\text { et al. }{ }^{15}(2013)\end{array}$ & $\begin{array}{l}\text { A comparative study of } \\
\text { antiplaque and antigingivitis } \\
\text { effects of herbal mouth rinse } \\
\text { containing tea tree oil, clove, } \\
\text { and basil with commercially } \\
\text { available essential oil mouth } \\
\text { rinses }\end{array}$ & $\begin{array}{l}\text { Patients coming to the Depart- } \\
\text { ment of Periodontics male } \\
\text { or female, nonsmokers aged } \\
\text { between } 18 \text { and } 35 \text { years with } \\
\text { a plaque index (PI; Silness and } \\
\text { Loe, 1964) and gingival index } \\
\text { (Gl; Loe and Silness, 1963) } \\
\text { score of }>1.5 \text { were included in } \\
\text { the study }\end{array}$ & $\begin{array}{l}\text { Fifty randomized, dou- } \\
\text { ble-blinded, controlled, } \\
\text { parallel-group design } \\
\text { clinical trial }\end{array}$ & $\begin{array}{l}\text { Newly formulated mouth rinse } \\
\text { containing TTO, clove, and basil } \\
\text { demonstrates antiplaque, antigin- } \\
\text { givitis, and antibacterial proper- } \\
\text { ties, which may be useful as an } \\
\text { adjunctive to mechanical therapy } \\
\text { in the prevention and treatment of } \\
\text { periodontal diseases }\end{array}$ \\
\hline $\begin{array}{l}\text { Prasad } \\
\text { et al. }{ }^{16}(2015)\end{array}$ & $\begin{array}{l}\text { Antiplaque efficacy of herbal } \\
\text { and } 0.2 \% \text { chlorhexidine } \\
\text { gluconate }(\mathrm{CHXg}) \\
\text { mouthwash: a comparative } \\
\text { study }\end{array}$ & $\begin{array}{l}\text { Fifty dental students from the } \\
\text { Department of Periodontics, } \\
\text { MNR Dental College, San- } \\
\text { gareddy }\end{array}$ & $\begin{array}{l}\text { A randomized, con- } \\
\text { trolled clinical study }\end{array}$ & $\begin{array}{l}\text { Within the limitations of the study, } \\
\text { CHXg and herbal mouthwash } \\
\text { (HiOra) showed similar antiplaque } \\
\text { activity with the latter showing no } \\
\text { side effects }\end{array}$ \\
\hline $\begin{array}{l}\text { Padiyar } \\
\text { et al. }{ }^{17}(2018)\end{array}$ & $\begin{array}{l}\text { Comparative evaluation of } \\
\text { effects of triphala, garlic ex- } \\
\text { tracts, and CHX mouthwash- } \\
\text { es on salivary Streptococcus } \\
\text { mutans counts and oral } \\
\text { hygiene status }\end{array}$ & $\begin{array}{l}\text { Students from a residential } \\
\text { ashram located in the campus } \\
\text { of Mahatma Gandhi University } \\
\text { of Medical Sciences and Tech- } \\
\text { nology, Sitapura, Jaipur, in the } \\
\text { age-group of 9-12 years }\end{array}$ & $\begin{array}{l}\text { Sixty students were } \\
\text { selected by a table of } \\
\text { random numbers, a } \\
\text { randomized controlled } \\
\text { trial }(\mathrm{RCT})\end{array}$ & $\begin{array}{l}\text { All the three mouthwashes } \\
\text { containing triphala, CHXg, and } \\
\text { garlic were comparably efficient } \\
\text { in reducing the salivary S. mutans } \\
\text { count as well as in limiting plaque } \\
\text { score; however, CHX was the most } \\
\text { effective in this aspect. In compari- } \\
\text { son of the two natural ingredients, } \\
\text { triphala is more effective in its } \\
\text { antimicrobial effect }\end{array}$ \\
\hline $\begin{array}{l}\text { Umar et al. }{ }^{18} \\
(2016)\end{array}$ & $\begin{array}{l}\text { The effect of pomegranate } \\
\text { mouth rinse on S. mutans } \\
\text { count and salivary } \mathrm{pH} \text {-an in } \\
\text { vivo study }\end{array}$ & Fifty patients aged $15-25$ years & $\begin{array}{l}\text { The selected patients } \\
\text { were randomly divided } \\
\text { into two groups of } 25 \\
\text { subjects each }\end{array}$ & $\begin{array}{l}\text { PPE mouth rinse possesses a } \\
\text { remarkable antimicrobial activity } \\
\text { against } S . \text { mutans present in the } \\
\text { oral cavity as tested in vivo, and } \\
\text { may be used as an adjunct to } \\
\text { prevent dental caries and maintain } \\
\text { good oral hygiene }\end{array}$ \\
\hline $\begin{array}{l}\text { Mali et al. }{ }^{19} \\
(2016)\end{array}$ & $\begin{array}{l}\text { Comparative evaluation of } \\
\text { arimedadi oil with } 0.2 \% \mathrm{CHXg} \\
\text { in prevention of plaque and } \\
\text { gingivitis-a randomized } \\
\text { clinical trial }\end{array}$ & $\begin{array}{l}\text { Forty-five patients aged } \\
\text { between 18-21 years, dental } \\
\text { students }\end{array}$ & $\begin{array}{l}\text { Randomized, dou- } \\
\text { ble-blinded, three- } \\
\text { group parallel study } \\
21 \text { days }\end{array}$ & $\begin{array}{l}\text { Arimedadi oil is equally effective } \\
\text { to } \mathrm{CHXg} \text { as an adjunct to mechani- } \\
\text { cal plaque control in the preven- } \\
\text { tion of plaque accumulation and } \\
\text { gingivitis }\end{array}$ \\
\hline $\begin{array}{l}\text { Abdulbaqi } \\
\text { et al. } .^{20}(2016)\end{array}$ & $\begin{array}{l}\text { Evaluation of Salvadora } \\
\text { persica L. and green tea anti- } \\
\text { plaque effect-a randomized } \\
\text { controlled crossover clinical } \\
\text { trial }\end{array}$ & $\begin{array}{l}25-40 \text { years in good general } \\
\text { health and with more than } 20 \\
\text { teeth }\end{array}$ & $\begin{array}{l}\text { Double-blinded, } \\
\text { randomized crossover } \\
\text { clinical trial conducted } \\
\text { on } 14 \text { participants }\end{array}$ & $\begin{array}{l}\text { This study demonstrates that } \\
\text { rinsing with } 15 \mathrm{~mL} \text { of } 0.25 \mathrm{mg} / \mathrm{mL} \\
\text { Gt and } 7.82 \mathrm{mg} / \mathrm{mL} \text { Sp aqueous } \\
\text { extracts combination twice daily } \\
\text { can significantly reduce plaque } \\
\text { accumulation after } 24 \text { hours re- } \\
\text { growth. The anti-plaque effect of } \\
\text { this combination was significantly } \\
\text { better than } 0.12 \% \mathrm{CHX}\end{array}$ \\
\hline
\end{tabular}




\begin{abstract}
Sedigh- A traditional mouthwash Rahimabadi (Punicagranatum var et al. ${ }^{21}$ (2017) pleniflora) for controlling gingivitis of diabetic patients-a double-blinded randomized controlled clinical trial

Mishra Antimicrobial efficacy of proet al. ${ }^{22}$ (2016) biotic and herbal oral rinses against Candida albicans in children-a randomized clinical trial

$\begin{array}{ll}\text { He et al. }^{23} & \text { Short-term microbiological } \\ \text { (2013) } & \text { effects of scaling and root } \\ & \text { planing (SRP) and essential } \\ & \text { oil mouthwash in Chinese } \\ & \text { adults }\end{array}$
\end{abstract}

Rezaei Comparison of the efficacy et al. ${ }^{24}$ (2016) of herbal mouthwash with CHX on the Gl of intubated patients in intensive care unit (ICU)

Tavakoli Evaluating the effect of Matet al. ${ }^{25}$ (2016) ricaria recutita and Mentha piperita herbal mouthwash on the management of oral mucositis (OM) in patients undergoing hematopoietic stem cell transplantation (HSCT) —a randomized, double-blinded, placebo-controlled clinical trial

Parwani Comparative evaluation of et al. $^{26}$ (2013) antiplaque efficacy of herbal and $0.2 \% \mathrm{CHXg}$ mouthwash in a 4-day plaque regrowth study

Priya et al. ${ }^{27}$ (2015)

Efficacy of $\mathrm{CHX}$ and green tea mouthwashes in the management of dental plaque-induced gingivitis-a comparative clinical study

Aghili et al. ${ }^{28}$ Antimicrobial effect of Zataria In this lab trial study, Iranian (2014) multiflora extract in compari- and foreign-made elastomeric son with $\mathrm{CHX}$ mouthwash on ligatures were experimentally experimentally contaminated contaminated in S. mutans, orthodontic elastomeric ligatures

Varghese Comparative evaluation of et al. ${ }^{29}$ (2018) efficacy of Murraya koenigii and $\mathrm{CHXg}$ in the treatment of gingivitis - a randomized controlled clinical trial
Eighty patients, 20-65 years, diabetic patients

Sixty subjects aged between 6 and 14 years attending the pedodontics outpatient unit

Fifty Chinese adults with chronic periodontitis

Seventy-six patients under mechanical ventilation of three ICUs of Teaching Hospital, Yazd, Iran, from May 2014, to September 2014

Sixty patients undergoing HSCT were randomly assigned to two groups: placebo $(n=33)$ and herbal mouthwash group $(n=27)$

Ninety preclinical dental students

Patients seeking periodontal treatment at Chettinad Dental College in an age-group of 18 and 24 years

Enterococcus faecalis, and $C$. albicans suspensions

Forty-five participants within the age-group of 20-45 years who reported to the outpatien department of periodontics of ber 2016, to January 2017 the institution, from Septem-
Two-armed, dou-blinded randomized traditional herbal $P$. granatum var comparative clinical trial, using a parallel design

A randomized clinical trial

Randomly assigned to full-mouth SRP or a 7-day essential oil mouthwash regimen In addition, 22 periodontally healthy adults used essential oil mouthwash for 7 days

Randomized, doubleblinded, controlled clinical trial

Randomized, doubleblinded, placebocontrolled trial

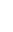

(n)
safe and effective modality in the patients as compared with $\mathrm{CHX}$ $(0.2 \%)$ mouthwash and may be considered a good alternative

Data obtained from the study was equally effective as $0.2 \%$ reducing $C$. albicans counts after rinse was least effective

SRP and essential oil mouthwash gingival plaque flora in Chinese periodontitis patients for 7 days, with greater microbiological improvement by SRP extract and $A$. vera gel extract in the mouthwash formula acts in ICUs

This study shows that patients receiving herbal mouthwash experienced less complications and symptoms associated with pleniflora (Golnar) mouthwash is a treatment of gingivitis in diabetic demonstrated that probiotic rinse chlorhexidine digluconate rinse in 1 week of intervention. Herbal oral both have an impact on saliva and

Combination of S. persica ethanol better than $\mathrm{CHX}$ in reducing the $\mathrm{Gl}$ of intubated hospitalized patients OM. The use of prepared herbal mouthwash is beneficial for patients undergoing HSCT

Examiner-blinded, parallel-designed clinical trial

Single-blinded, randomized controlled trial

In vitro study

Double-blinded, randomized controlled clinical trial

(n)

(n)

It was concluded that $0.2 \% \mathrm{CHXg}$ mouthwash remains the best antiplaque agent. However, when socioeconomic factor and/or side effects of CHX need consideration, presently tested herbal mouthwash may be considered as a good alternative

The green tea-containing mouthwash is equally effective in reducing the gingival inflammation and plaque to $\mathrm{CHX}$

Zataria multiflora extract has antimicrobial properties and can be used for disinfection of elastomeric ligatures

M. koenigii mouthwash is equally effective as $\mathrm{CHX}$, in treating plaque-induced gingivitis 
Table 1: (Contd...)

studying in New Horizon

Dental College and Research Institute formed the study population

\begin{tabular}{|c|c|c|c|c|}
\hline $\begin{array}{l}\text { Author and } \\
\text { year }\end{array}$ & Title & Target population & $\begin{array}{l}\text { Sample size and } \\
\text { Study design }\end{array}$ & Conclusion \\
\hline $\begin{array}{l}\text { Balappanavar } \\
\text { et al. }{ }^{30}(2013)\end{array}$ & $\begin{array}{l}\text { Comparison of the effective- } \\
\text { ness of } 0.5 \% \text { tea, } 2 \% \text { neem, } \\
\text { and } 0.2 \% \mathrm{CHX} \text { mouthwashes } \\
\text { on oral health-a rand- } \\
\text { omized controlled trial }\end{array}$ & $\begin{array}{l}\text { Thirty healthy human volun- } \\
\text { teers of age-group 18-25 years }\end{array}$ & $\begin{array}{l}\text { Triple-blinded, ran- } \\
\text { domized controlled, } \\
\text { parallel design trial }\end{array}$ & $\begin{array}{l}\text { The effectiveness of } 0.5 \% \text { tea was } \\
\text { more compared to } 2 \% \text { neem and } \\
0.2 \% \text { CHX mouth rinse }\end{array}$ \\
\hline $\begin{array}{l}\text { Chatterjee } \\
\text { et al. }{ }^{31}(2017)\end{array}$ & $\begin{array}{l}\text { A comparative evaluation of } \\
\text { the efficacy of curcumin and } \\
\text { CHX mouth rinses on clinical } \\
\text { infl ammatory parameters of } \\
\text { gingivitis-a double-blinded, } \\
\text { randomized controlled } \\
\text { clinical study }\end{array}$ & $\begin{array}{l}\text { Subjects of age-group of } \\
20-40, \text { with minimum } 20 \\
\text { permanent erupted teeth, } \\
\text { mild-to-moderate gingivitis }\end{array}$ & $\begin{array}{l}\text { One hundred fifty } \\
\text { double-blinded, } \\
\text { randomized controlled } \\
\text { clinical trial }\end{array}$ & $\begin{array}{l}\text { Curcumin mouthwash has shown } \\
\text { antiplaque and antigingivitis prop- } \\
\text { erties comparable to CHX mouth- } \\
\text { wash. Thus, curcumin mouthwash } \\
\text { and } \mathrm{CHXg} \text { can be effectively used } \\
\text { as an adjunct to scaling and root } \\
\text { planning }\end{array}$ \\
\hline $\begin{array}{l}\text { Yadav et al. }{ }^{32} \\
(2017)\end{array}$ & $\begin{array}{l}\text { Effect of green coffee } \\
\text { bean extract on S. mutans } \\
\text { count-a randomized } \\
\text { controlled trial }\end{array}$ & $\begin{array}{l}\text { Sample size of } 45 \text { subjects, in } \\
\text { the age-group, ranging from } \\
18 \text { to } 22 \text { years was selected } \\
\text { among the students of a } \\
\text { dental institute }\end{array}$ & $\begin{array}{l}\text { Randomized, parallel } \\
\text { controlled clinical trial }\end{array}$ & $\begin{array}{l}\text { Green coffee bean extract shows a } \\
\text { statistical significant reduction in } \\
\text { S. mutans count and hence should } \\
\text { be considered an alternative } \\
\text { mouth rinse due to its herbal and } \\
\text { additional health benefits over the } \\
\text { human body }\end{array}$ \\
\hline $\begin{array}{l}\text { Cullinan } \\
\text { et al. }{ }^{33}(1997)\end{array}$ & $\begin{array}{l}\text { Efficacy of a dentifrice and } \\
\text { oral rinse containing Sangui- } \\
\text { naria extract in conjunction } \\
\text { with initial periodontal } \\
\text { therapy }\end{array}$ & $\begin{array}{l}\text { Thirty-four patients attending } \\
\text { the Periodontal Clinic at the } \\
\text { University of Queensland } \\
\text { Dental School participated }\end{array}$ & $\begin{array}{l}\text { Randomized, } \\
\text { double-blinded parallel } \\
\text { design clinical trial }\end{array}$ & $\begin{array}{l}\text { There was no significant advan- } \\
\text { tage to the Sanguinaria group. } \\
\text { Results demonstrate that initial } \\
\text { therapy in the form of oral hygiene } \\
\text { instruction and SRP leads to a } \\
\text { significant improvement in perio- } \\
\text { dontal status, which is maintained } \\
\text { at least in the short term. Further, } \\
\text { the use of a dentifrice and oral } \\
\text { rinse containing Sanguinaria did } \\
\text { not improve the efficacy of initial } \\
\text { therapy }\end{array}$ \\
\hline $\begin{array}{l}\text { Braga et al. }{ }^{34} \\
(2015)\end{array}$ & $\begin{array}{l}\text { Use of Chamomilla recutita in } \\
\text { the prevention and treatment } \\
\text { of OM in patients undergoing } \\
\text { HSCT }\end{array}$ & $\begin{array}{l}\text { Forty patients from inpatient } \\
\text { unit for adult and pediatric } \\
\text { patients undergoing HSCT at a } \\
\text { Brazilian Hospital, specializing } \\
\text { in cancer }\end{array}$ & $\begin{array}{l}\text { Randomized, controlled, } \\
\text { phase II clinical trial } \\
\text { (phase II RCT), with } \\
\text { parallel groups }\end{array}$ & $\begin{array}{l}\text { In this study, the use of a mouth- } \\
\text { wash containing the liquid extract } \\
\text { of } C \text {. recutita at a } 1 \% \text { dosage } \\
\text { (equivalent to } 0.108 \text { mg of api- } \\
\text { genin-7-glucoside per milliliters of } \\
\text { product) can be associated with } \\
\text { reduced incidence, intensity, and } \\
\text { duration of mucositis in adult pa- } \\
\text { tients undergoing allogenic HSCT }\end{array}$ \\
\hline $\begin{array}{l}\text { Akca et al. }{ }^{35} \\
(2016)\end{array}$ & $\begin{array}{l}\text { Comparative evaluation of } \\
\text { the antimicrobial effect of } \\
\text { propolis with } \mathrm{CHX} \text { against } \\
\text { oral pathogens-an in vitro } \\
\text { study }\end{array}$ & $\begin{array}{l}\text { The minimum inhibitory } \\
\text { concentration (MIC) and the } \\
\text { minimum bactericidal concen- } \\
\text { tration for both antimicrobial } \\
\text { agents were determined by } \\
\text { conducting agar dilution } \\
\text { and broth microdilution test } \\
\text { methods }\end{array}$ & In vitro study & $\begin{array}{l}\text { Based on our results, we may } \\
\text { conclude that the administration } \\
\text { of propolis at appropriate concen- } \\
\text { trations might be effective on oral } \\
\text { microorganisms. Although CHX } \\
\text { is still one of the most common } \\
\text { oral rinse products against a wide } \\
\text { range of microorganisms, ethanol- } \\
\text { ic extract of propolis may serve as } \\
\text { an alternative natural and reliable } \\
\text { antimicrobial mouth rinse in order } \\
\text { to avoid the side effects of } \mathrm{CHX}\end{array}$ \\
\hline $\begin{array}{l}\text { Vangipuram } \\
\text { et al. }{ }^{36}(2016)\end{array}$ & $\begin{array}{l}\text { Comparative efficacy of aloe } \\
\text { vera mouthwash and } \mathrm{CHX} \text { on } \\
\text { periodontal health-a RCT }\end{array}$ & $\begin{array}{l}\text { Three hundred ninety ( } 390) \\
\text { undergraduate and postgrad- } \\
\text { uate dental students among } \\
\text { the age-group of } 18-40 \text { years, }\end{array}$ & $\mathrm{RCT}$ & $\begin{array}{l}\text { It can be concluded from the pres- } \\
\text { ent study that aloe vera mouth- } \\
\text { wash is equally effective as } \mathrm{CHX} \text { in } \\
\text { reducing plaque and gingivitis }\end{array}$ \\
\hline
\end{tabular}




\begin{tabular}{|c|c|c|c|c|}
\hline $\begin{array}{l}\text { Beheshti- } \\
\text { Rouy et al. }{ }^{37} \\
\text { (2014) }\end{array}$ & $\begin{array}{l}\text { The antibacterial effect of } \\
\text { sage extract (Salvia officina- } \\
\text { lis) mouthwash against } S \text {. } \\
\text { mutans in dental plaque-a } \\
\text { randomized clinical trial }\end{array}$ & $\begin{array}{l}\text { School children of Hamadan, } \\
\text { Iran, aged } 11-14 \text { years }\end{array}$ & $\begin{array}{l}\text { Double-blinded, rand- } \\
\text { omized clinical trial }\end{array}$ & $\begin{array}{l}\text { The Sage mouthwash effectively } \\
\text { reduced the number of S. mutans } \\
\text { in dental plaque }\end{array}$ \\
\hline $\begin{array}{l}\text { Gupta et al. }{ }^{38} \\
(2018)\end{array}$ & $\begin{array}{l}\text { Effect of cinnamon extract } \\
\text { and } \mathrm{CHXg}(0.2 \%) \text { on the clini- } \\
\text { cal level of dental plaque and } \\
\text { gingival health-a 4-week, } \\
\text { triple-blinded, RCT }\end{array}$ & $\begin{array}{l}\text { One hundred five volunteers } \\
\text { from the Department of Public } \\
\text { Health Dentistry on male and } \\
\text { female university students }\end{array}$ & $\begin{array}{l}\text { Triple-blinded, RCT, a } \\
\text { three-group parallel } \\
\text { study }\end{array}$ & $\begin{array}{l}\text { Within the limitation of this trial, } \\
\text { cinnamon has been shown to } \\
\text { demonstrate similar effects on } \\
\text { plaque and gingivitis compared to } \\
\text { the benchmark control, CHX }\end{array}$ \\
\hline $\begin{array}{l}\text { Freires et al. }{ }^{39} \\
(2013)\end{array}$ & $\begin{array}{l}\text { A randomized clinical trial } \\
\text { of Schinus terebinthifolius } \\
\text { (ST) mouthwash to treat } \\
\text { biofilm-induced gingivitis }\end{array}$ & $\begin{array}{l}\text { Children aged } 9-13 \text { years } \\
(n=27) \text {, presenting with bio- } \\
\text { film-induced gingivitis }\end{array}$ & $\begin{array}{l}\text { Randomized, controlled, } \\
\text { triple-blinded, and } \\
\text { phase II clinical trial }\end{array}$ & $\begin{array}{l}\text { ST mouthwash showed significant } \\
\text { anti-inflammatory activity (equiva- } \\
\text { lent to } \mathrm{CHX} \text { ), but it was not able to } \\
\text { reduce biofilm accumulation }\end{array}$ \\
\hline
\end{tabular}

room temperature at least for 1 hour and then strained the tea with a sieve. Discarded loose tea. Then, $500 \mathrm{~mL}$ of strenuous tea was mixed with $1000 \mathrm{~mL}$ of distilled water to get a $0.5 \%$ solution of tea mouthwash. ${ }^{30}$

\section{Curcumin Mouthwash}

The main ingredient used in this formulation was Curcumin (diferuloylmethane), a polyphenol derived from Curcuma longa plant, which contains raw turmeric in the quantity of $0.3-5.4 \%$. Turmeric contains various active ingredients, like flavonoid curcumin and volatile oils including turmerone, atlantone, and zingiberone. It also contains sugars, proteins, and resins. ${ }^{31}$

\section{Green Coffee Bean Extract Mouthwash}

A $2 \%$ green coffee bean extract was prepared by dissolving $2 \mathrm{~g}$ of the powder in $100 \mathrm{~mL}$ of distilled water. ${ }^{32}$

\section{Chamomilla recutita Mouthwash}

Liquid extract of $C$. recutita, sodium benzoate preservative, sodium saccharide sweetener, methylparaben preservative, menthol refresher, mint aroma corrective, polyethylene glycol (PEG) 40 tensoactive, sorbitol co-tensoactive, glycerol co-tensoactive, and purified water quantity sufficient were used as a vehicle to get $C$. recutita mouthwash. ${ }^{34}$

\section{Propolis Extract Mouthwash}

After weighing $20 \mathrm{~g}$ of unrefined propolis, it was dissolved in $100 \mathrm{~mL}$ of $80 \%$ ethanol via ultrasonic bath at $40^{\circ} \mathrm{C}$ for 2 hours. The solution was strained through Whatman and Protran nitrocellulose membranes. Dried the solution by evaporating through nitrogen flow. Mixed approximately $5 \mu \mathrm{g}$ of residual material with $75 \mu \mathrm{L}$ of dry pyridine and $50 \mu \mathrm{L}$ of bis-trimethylsilyl trifluoroacetamide, which was then heated at $80^{\circ} \mathrm{C}$ for $20 \mathrm{~min}$. The ultimate supernatant was analyzed by gas chromatography-mass spectrometry. ${ }^{35}$

\section{Aloe Vera Mouthwash}

Aloe vera juice is made up of $99 \%$ aloe juice, $0.2 \%$ preservative, $0.001 \%$ spearmint flavor, and sweetened with sorbitol. ${ }^{36}$

\section{Sage Extract Mouthwash}

Sage mouthwash is prepared from the plant Salvia officinalis. Chop the plant leaves to fragment into pieces, soak $50 \mathrm{~g}$ of leaves in $1500 \mathrm{~mL}$ of ethanol solvent in a shaker apparatus at $90 \mathrm{rpm}$ for 48 hours. Solution passed through a strainer and transferred to a rotary evaporator apparatus to separate the solvent from the extract. A $5 \%$ Sage mouthwash was prepared $(0.5 \mathrm{~g}$ of extract in $100 \mathrm{~mL}$ of distilled water) and poured into bottles, each containing $240 \mathrm{~mL}$ of the solution. ${ }^{37}$

\section{Mixed Herbal Mouthwash}

Mixed herbal mouthwash comprises Babool chaal/Acacia arabica $(20 \% \mathrm{w} / \mathrm{v})$, darim leaves/Punica granatum $(10 \% \mathrm{w} / \mathrm{v})$, chameli leaves/ Jasminum grandiflorum (10\% w/v), mulethi/Glycyrrhiza glabra $(5 \% \mathrm{w} / \mathrm{v})$, neem/Azadirachta indica $(2 \% \mathrm{w} / \mathrm{v})$. The role of various ingredients is included as follows:

Babool chaal-astringent, Astringent-astringent, chameli leaves-antimicrobial, mulethi-astringent, and neem-astringent and an antimicrobial agent.

It consists of other ingredients as well, like alum $(1.5 \% \mathrm{w} / \mathrm{v})$, suhaga $(1 \% \mathrm{w} / \mathrm{v})$, kapoor $(0.5 \% \mathrm{w} / \mathrm{v})$, laung $(1 \% \mathrm{w} / \mathrm{v})$, and menthol $(0.5 \% \mathrm{w} / \mathrm{v}) .^{26}$

\section{Cinnamon Extract Mouthwash}

Fresh cinnamon bark was ground to a fine powder with the help of a mechanical grinder. Then in $100 \mathrm{~mL}$ of deionized water, $10 \mathrm{~g}$ of finely powdered cinnamon was added and kept in a water bath in a round-bottomed flask for 5 hours at 55 to $60^{\circ} \mathrm{C}$, then filtered through a sterile filter paper (Whatman, UK). The aqueous extract was decanted, clarified by filtration through a muslin cloth, and evaporated in a porcelain dish at $40^{\circ} \mathrm{C}$, which resulted in a dried extract. In the end, this dried extract was poised in PEG $400(20 \% \mathrm{v} / \mathrm{v})$ and sterile distilled water to give a final concentration of $20 \% \mathrm{w} / \mathrm{v} .{ }^{38}$

\section{Schinus terebinthifolius Mouthwash}

It comprised the stem bark tincture of S. terebinthifolius and the lowest concentration required for suppressing the growth of bacteria was seen to be $0.3125 \%$. Phytochemical profile of $S$. terebinthifolius showed triterpenes, flavonoids, steroids, saponins, and tannins. The antimicrobial and anti-inflammatory properties were attributed to the phytoconstituents present in it. ${ }^{39}$

\section{Conclusion}

A variety of mouthwashes can be prescribed depending on the oral diseases. Hence, oral healthcare practitioners must have to be cognizant of various etiologic factors and predisposing conditions of the oral cavity. Of course, it goes without saying that chlorhexidine is the gold standard mouthwash. However, when socioeconomic factors, side effects, and/or liking of the population for natural products need consideration, herbal mouthwashes may 
be considered as a good alternative. However, further studies can be done to extrapolate the advantages and disadvantages of these herbal products.

\section{Clinical Significance}

Augmented bacterial resistance toward antibiotics or side effects of chemical antiplaque agents there is substantial interest in the advancement of other classes of antimicrobial agents for control of infection and better oral health. The use of an indigenous herbal mouthwash can improve the oral health status of an individual.

\section{References}

1. Page RC, Kornman KS. The pathogenesis of human periodontitis: an introduction. Periodontol 2000 1997;14(1):9-11. DOI: 10.1111/j.16000757.1997.tb00189.x.

2. DePaola LG, Overholser CD, Meiller TF, et al. Chemotherapeutic inhibition of supragingival dental plaque and gingivitis development. J Clin Periodontol 1989;16(5):311-315. DOI: 10.1111/j.1600-051x.1989. tb01661.x.

3. Dona BL, Gründemann LJ, Steinfort J, et al. The inhibitory effect of combining chlorhexidine and hydrogen peroxide on 3rd day plaque accumulation. J Clin Periodontol 1998;25(11 Pt 1):879-883. DOI: 10.1111/j.1600-051x.1998.tb02385.x.

4. Siddeshappa ST, Bhatnagar S, Yeltiwar RK, et al. Comparative evaluation of antiplaque and antigingivitis effects of an herbal and chlorine dioxide mouthwashes: a clinicomicrobiological study. Indian J Dent Res 2018;29(1):34. DOI: 10.4103/ijdr.IJDR_391_16.

5. Albert-Kiszely A, Pjetursson BE, Salvi GE, et al. Comparison of the effects of cetylpyridinium chloride with an essential oil mouth rinse on dental plaque and gingivitis - a six month randomized controlled clinical trial. J Clin Periodontol 2007;34(8):658-667. DOI: 10.1111/j.1600-051X.2007.01103.x.

6. Najafi MH, Taheri M, Mokhtari MR, et al. Comparative study of $0.2 \%$ and $0.12 \%$ digluconate chlorhexidine mouth rinses on the level of dental staining and gingival indices. Dent Res J (Isfahan) 2012;9(3):305. drj.mui.ac.ir/index.php/drj/article/view/1089

7. Kaur $\mathrm{H}$, Jain $\mathrm{S}$, Kaur A. Comparative evaluation of the antiplaque effectiveness of green tea catechin mouthwash with chlorhexidine gluconate. J Indian Soc Periodontol 2014;18(2):178-182. DOI: 10.4103/0972-124X.131320.

8. Pizzo G, Guiglia R, Imburgia M, et al. The effects of antimicrobial sprays and mouthrinses on supragingival plaque regrowth: a comparative study. J Periodontol 2006;77(2):248-256. DOI: 10.1902/ jop.2006.050116.

9. Gupta D, Nayan S, Tippanawar HK, et al. Are herbal mouthwash efficacious over chlorhexidine on the dental plaque? Pharmacognosy Res 2015;7(3):277-281. DOI: 10.4103/0974-8490.155874.

10. Bhat N, Mitra R, Reddy JJ, et al. Evaluation of efficacy of chlorhexidine and a herbal mouthwash on dental plaque: an in vitro comparative study. Int J Pharm Bio Sci 2013;4(3):625-632. Available from: https:// www.researchgate.net/publication/269404420

11. Mahajan R, Khinda P, Gill A, et al. Comparison of efficacy of $0.2 \%$ chlorhexidine gluconate and herbal mouthrinses on dental plaque: an in vitro comparative study. Eur J Med Plants 2016;13(2):1-11. DOI: 10.9734/EJMP/2016/23318.

12. Mali AM, Behal R, Gilda SS. Comparative evaluation of $0.1 \%$ turmeric mouthwash with $0.2 \%$ chlorhexidine gluconate in prevention of plaque and gingivitis: a clinical and microbiological study. J Indian Soc Periodontol 2012;16(3):386-391. DOI: 10.4103/0972124X.100917.

13. Manipal $S$, Hussain $S$, Wadgave $U$, et al. The mouthwash warchlorhexidine vs. herbal mouth rinses: a meta-analysis. J Clin Diagn Res 2016;10(5):81. DOI: 10.7860/JCDR/2016/16578.7815.

14. Naiktari RS, Gaonkar P, Gurav AN, et al. A randomized clinical trial to evaluate and compare the efficacy of triphala mouthwash with $0.2 \%$ chlorhexidine in hospitalized patients with periodontal diseases. J Periodontal Implant Sci 2014;44(3):134-140. DOI: 10.5051/ jpis.2014.44.3.134.

15. Kothiwale SV, Patwardhan V, Gandhi M, et al. A comparative study of antiplaque and antigingivitis effects of herbal mouthrinse containing tea tree oil, clove, and basil with commercially available essential oil mouthrinse. J Indian Soc Periodontol 2014;18(3):316. DOI: 10.4103/0972-124X.134568.

16. Prasad KR, John S, Deepika V, et al. Anti-plaque efficacy of herbal and $0.2 \%$ chlorhexidine gluconate mouthwash: a comparative study. J Int Oral Health 2015;7(8):98. "https://dx.doi.org/10.5812/ ijo.96472"10.5812/ijo.96472

17. Padiyar B, Marwah N, Gupta S, et al. Comparative evaluation of effects of triphala, garlic extracts, and chlorhexidine mouthwashes on salivary Streptococcus mutans counts and oral hygiene status. Int J Clin Pediatr Dent 2018;11(4):299. DOI: 10.5005/ jp-journals-10005-1530.

18. Umar D, Dilshad B, Farhan M, et al. The effect of pomegranate mouthrinse on Streptococcus mutans count and salivary $\mathrm{pH}$ : an in vivo study. J Adv Pharm Technol Res 2016;7(1):13. DOI: 10.4103/22314040.173266.

19. Mali GV, Dodamani AS, Karibasappa GN, et al. Comparative evaluation of Arimedadi oil with $0.2 \%$ chlorhexidine gluconate in prevention of plaque and gingivitis: a randomized clinical trial. J Clin Diagn Res 2016;10(7):31. DOI: 10.7860/JCDR/2016/19120.8132.

20. Abdulbaqi HR, Himratul-Aznita WH, Baharuddin NA. Evaluation of Salvadora persica $\mathrm{L}$. and green tea anti-plaque effect: a randomized controlled crossover clinical trial. BMC Complement Altern Med 2016;16(1):493. DOI: 10.1186/s12906-016-1487-0.

21. Sedigh-Rahimabadi M, Fani M, Rostami-chijan M, et al. A traditional mouthwash (Punica granatum var pleniflora) for controlling gingivitis of diabetic patients: a double-blinded randomized controlled clinical trial. J Evid Based Complementary Altern Med 2017;22(1):59-67. DOI: 10.1177/2156587216633370.

22. Mishra R, Tandon S, Rathore M, et al. Antimicrobial efficacy of probiotic and herbal oral rinses against Candida albicans in children: a randomized clinical trial. Int J Clin Pediatr Dent 2016;9(1):25. DOI: 10.5005/jp-journals-10005-1328.

23. He JY, Qi GG, Huang WJ, et al. Short-term microbiological effects of scaling and root planing and essential-oils mouthwash in Chinese adults. J Zhejiang Univ Sci B 2013;14(5):416-425. DOI: 10.1631/jzus. B1200350.

24. Rezaei S, Rezaei K, Mahboubi M, et al. Comparison the efficacy of herbal mouthwash with chlorhexidine on gingival index of intubated patients in Intensive Care Unit. J Indian Soc Periodontol 2016;20(4):404. DOI: 10.4103/0972-124X.194269.

25. Ardakani MT, Ghassemi S, Mehdizadeh M, et al. Evaluating the effect of Matricaria recutita and Mentha piperita herbal mouthwash on management of oral mucositis in patients undergoing hematopoietic stem cell transplantation: A randomized, double blind, placebo controlled clinical trial. Complement Ther Med 2016;29:29-34. DOI: 10.1016/j.ctim.2016.08.001.

26. Parwani SR, Parwani RN, Chitnis PJ, et al. Comparative evaluation of anti-plaque efficacy of herbal and $0.2 \%$ chlorhexidine gluconate mouthwash in a 4-day plaque re-growth study. J Indian Soc Periodontol 2013;17(1):72. DOI: 10.4103/0972-124X.107478.

27. Priya BM, Anitha V, Shanmugam M, et al. Efficacy of chlorhexidine and green tea mouthwashes in the management of dental plaqueinduced gingivitis: a comparative clinical study. Contemp Clin Dent 2015;6(4):505. DOI: 10.4103/0976-237X.169845.

28. Aghili $H$, Nadoushan AA, Herandi V. Antimicrobial effect of zataria multiflora extract in comparison with chlorhexidine mouthwash on experimentally contaminated orthodontic elastomeric ligatures. J Dent (Tehran) 2015;12(1):1. https://pubmed.ncbi.nIm.nih. gov/26005448

29. Varghese A, Babu HM, Kukkera PN. Comparative evaluation of efficacy of Murraya koenigii and chlorhexidine gluconate in the treatment of gingivitis: a randomized controlled clinical trial. J Indian Soc Periodontol 2018;22(5):427. DOI: 10.4103/jisp.jisp_112_18. 
30. Balappanavar AY, Sardana V, Singh M. Comparison of the effectiveness of $0.5 \%$ tea, $2 \%$ neem and $0.2 \%$ chlorhexidine mouthwashes on oral health: a randomized control trial. Indian J Dent Res 2013;24(1):26. DOI: 10.4103/0970-9290.114933.

31. Chatterjee A, Debnath K, Rao NK. A comparative evaluation of the efficacy of curcumin and chlorhexidine mouthrinses on clinical inflammatory parameters of gingivitis: a double-blinded randomized controlled clinical study. J Indian Soc Periodontol 2017;21(2):132. DOI: 10.4103/jisp.jisp_136_17.

32. Yadav M, Kaushik M, Roshni R, et al. Effect of green coffee bean extract on Streptococcus mutans count: a randomised control trial. J Clin Diagn Res 2017;11(5):68. DOI: 10.7860/JCDR/2017/25743.9898.

33. Cullinan MP, Powell RN, Faddy MJ, et al. Efficacy of a dentifrice and oral rinse containing sanguinaria extract in conjunction with initial periodontal therapy. Aust Dent J 1997;42(1):47-51. DOI: 10.1111/j.18347819.1997.tb00096.x.

34. Braga FT, Santos AC, Bueno PC, et al. Use of Chamomilla recutita in the prevention and treatment of oral mucositis in patients undergoing hematopoietic stem cell transplantation: a randomized, controlled, phase II clinical trial. Cancer Nurs 2015;38(4):322-329. DOI: 10.1097/ NCC.0000000000000194.
35. Akca AE, Akca G, Topçu FT, et al. The comparative evaluation of the antimicrobial effect of propolis with chlorhexidine against oral pathogens: an in vitro study. Biomed Res Int 2016;2016:3627463. DOI: $10.1155 / 2016 / 3627463$.

36. Vangipuram S, Jha A, Bhashyam M. Comparative efficacy of aloe vera mouthwash and chlorhexidine on periodontal health: a randomized controlled trial. J Clin Exp Dent 2016;8(4):442. DOI: 10.4317/jced.53033.

37. Beheshti-Rouy M, Azarsina M, Rezaie-Soufi L, et al. The antibacterial effect of sage extract (Salvia officinalis) mouthwash against Streptococcus mutans in dental plaque: a randomized clinical trial. Iran J Microbiol 2015;7(3):173. https://pubmed.ncbi.nlm.nih. gov/26668706

38. Gupta D, Jain A. Effect of cinnamon extract and chlorhexidine gluconate $(0.2 \%)$ on the clinical level of dental plaque and gingival health: a 4-week, triple-blind randomized controlled trial. J Int Acad Periodontol 2015;17(3):91-98. https://pubmed.ncbi.nlm.nih. gov/26373226

39. Freires ID, Alves LA, Ferreira GL, et al. A randomized clinical trial of Schinus terebinthifolius mouthwash to treat biofilm-induced gingivitis. J Evid Based Complement Alternat Med 2013;2013:873907. DOI: 10.1155/2013/873907. 